Tersedia Online di: http://ojs.umrah.ac.id/index.php/gantang/index

\title{
DESAIN PEMBELAJARAN \\ LOGARITMA UNTUK SISWA SMA \\ KELAS X
}

\author{
Resti Madiana Lestari ${ }^{1}$, Rully Charitas Indra Prahmana ${ }^{2}$ \\ restimadianalestari@gmail.com, ${ }^{1}$ rully.indra@mpmat.uad.ac.id \\ 1,2Universitas Ahmad Dahlan \\ 2018
}

\begin{abstract}
Abstrak
Tujuan penelitian ini adalah untuk mengetahui peran desain pembelajaran logaritma dalam pengenalan konsep logaritma dan mengetahui hasil belajar siswa dalam pembelajaran logaritma melalui Lembar Aktivitas Siswa (LAS) berbasis pendekatan pembelajaran Pendidikan Matematika Realistik (PMR). Penelitian ini menggunakan metode penelitian design research, yang dilaksanakan di salah satu Sekolah Menengah Atas di Yogyakarta. Instrumen yang digunakan adalah instrumen tes tertulis, video, dan catatan lapangan. Hasil penelitian menunjukkan bahwa pada pertemuan ke-1 dan ke-2 siswa beradaptasi dengan desain pembelajaran yang diterapkan. Pada pertemuan selanjutnya, siswa dapat mengikuti kegiatan pembelajaran dengan lebih baik. Selain itu, hasil belajar siswa menunjukkan bahwa nilai rata-rata yang diperoleh siswa adalah 77,5 dengan frekuensi ketuntasan $65,6 \%$.
\end{abstract}

Kata kunci: Design Research, Desain Pembelajaran Logaritma, Pendidikan Matematika Realistik

\begin{abstract}
The study aims to know the role of logarithm learning design to introducing logarithm concept and the result at logarithm learning process through student worksheet based on Realistic Mathematics Education approach. The research method used is design research which was implemented in one of the Senior High School in Yogyakarta. The instruments used are test, video, and fieldnote. The result shows that the students look likes still adapt to learning design that implemented in the $1^{\text {st }}$ and $2^{\text {nd }}$ meeting, but in the next meeting the students can already start to follow learning process. Furthermore, the students result study show that the students' average value is 77.5 with frequency of completeness $65.6 \%$.

Keywords: Design Research, Logarithm Learning Designing, Realistic Mathematics Education
\end{abstract}

\section{Pendahuluan}

Logaritma adalah salah satu materi matematika peminatan yang diajarkan pada Sekolah Menengah Atas (SMA) kelas X (Permendikbud, 2016). Selanjutnya, logaritma adalah materi matematika yang dianggap sulit bagi siswa, sehingga untuk memudahkan siswa memahami materi logaritma dibutuhkan kegiatan belajar-mengajar yang bermakna dan pemahaman yang baik pada materi prasyarat 


\section{JURNAL GANTANG. Maret 2018; III(1): 31 - 39 \\ p-ISSN. 2503-0671 \\ e-ISSN. 2548-5547}

(Widowati, 2013: 266). Siswa harus dapat menguasai konsep dan sifat-sifat logaritma sebelum mempelajari fungsi logaritma (Sinaga dkk, 2014: 53). Oleh karena itu, diperlukan kegiatan pembelajaran yang bermakna agar siswa dapat menguasai konsep dan sifat-sifat logaritma yang merupakan materi prasyarat untuk fungsi logaritma.

Terdapat banyak siswa yang mengalami kesulitan untuk menguasai konsep logaritma, dikarenakan materi logaritma merupakan materi yang benar-benar baru bagi siswa kelas X Imersi SMA Negeri Karangpandan Karanganyar (Pawestri dkk, 2013: 2). Selanjutnya, faktor penyebab kesulitan siswa pada materi logaritma adalah prosedur pembelajaran matematika yang lebih mementingkan ketercapaian materi dari pada pemahaman materi atau konsep kepada siswa (Kusuma \& Masduki, 2016: 1). Oleh sebab itu, kesulitan siswa terhadap materi logaritma disebabkan materi yang baru serta prosedur pembelajaran yang belum baik.

Pendidikan Matematika Realistik (PMR) adalah suatu pendekatan pembelajaran yang dimulai dengan cara menghubungkan permasalahan matematika dengan masalahmasalah nyata sehingga dapat menciptakan pembelajaran yang bermakna (Fitriani, 2016: 343; Sari, Hadiyan, \& Antari, 2018: 69; Nurhayanti dkk, 2016: 66; Revina \& Leung, 2018: 2). Pendidikan Matematika Realistik di Indonesia dikenal sebagai Pendidikan Matematika Realistik Indonesia (PMRI) yang merupakan adaptasi dari Realistic Mathematics Education (RME) yang dikembangkan di Universitas Utrecht Belanda oleh Hans Freudenthal (Permatasari \& Harta, 2018: 83; Prahmana dkk, 2015: 3; Negara dkk, 2013: 700; Sembiring, 2010: 12; Ryandi, Somakim, \& Susanti, 2018: 107). Hingga saat ini PMR sudah diterapkan pada sekolah tingkat dasar hingga ke tingkat perguruan tinggi untuk kegiatan pembelajaran maupun penelitian (Putri dkk, 2015: 11). Selanjutnya, hasil penelitian menunjukkan bahwa pendidikan matematika realistik dapat diterapkan untuk mengenalkan materi logaritma (Webb dkk, 2011). Oleh sebab itu, pendidikan matematika realistik dapat diterapkan untuk pembelajaran materi logaritma untuk siswa kelas X.

Hasil penelitian yang dilakukan Lestari dan Prahmana (2017) menunjukkan bahwa model pembelajaran guided inquiry mempengaruhi kemampuan penalaran matematis siswa pada materi eksponen yang merupakan materi prasyarat untuk mempelajari materi logaritma. Sejalan dengan itu, guided inquiry atau istilah yang digunakan oleh Hans Freudhental adalah guided reinvention merupakan salah satu prinsip dari pendidikan matematika realistik (Freudhental, 2002: 45). Selanjutnya, terdapat 3 tahapan desain pembelajaran materi logaritma dengan menggunakan pendekatan matematika realistik, yaitu (1) memberikan permasalahan eksponensial yang ada didunia nyata untuk memantik siswa memahami kembali konsep eksponen (2) fokus pada materi mengenai fungsi dan sifat-sifat eksponen, karena materi eksponen merupakan materi prasyarat untuk mempelajari logaritma dan (3) mengenalkan materi logaritma melalui permasalahan yang ada didunia nyata (Webb dkk, 2011).

Berdasarkan uraian di atas, peneliti tertarik untuk merancang suatu desain pembelajaran materi logaritma untuk siswa kelas $X$. Harapannya ini dapat membantu siswa dalam memahami materi logaritma.

\section{Metode Penelitian}

Metode yang digunakan dalam penelitian ini adalah desugn research. Penelitian ini dilakukan di SMA Negeri 1 Jetis Bantul Yogyakarta. Penelitian ini dilakukan pada semester genap tahun akademik 2017/2018. Subjek penelitian ini adalah seluruh siswa kelas X MIPA 1 SMA N 1 Jetis Bantul, Yogyakarta. Objek pada penelitian ini adalah pengenalan konsep logaritma.

Teknik pengumpulan data yang digunakan dalam penelitian ini adalah rekaman video, dokumentasi, data tertulis, dan obervasi (Prahmana, 2017: 31). Selanjutnya, Instrumen 
penelitian merupakan alat yang digunakan untuk mendapatkan data dalam suatu penelitian. Instrumen yang digunakan dalam penelitian yaitu video, lembar tes tertulis siswa, dan lembar catatan lapangan. Data yang diperoleh pada penelitian di analisis dengan cara analisis data, validitas, dan reliabilitas (Prahmana, 2017: 32).

\section{Hasil dan Pembahasan}

Penelitian ini dilaksanakan sebanyak 3 kali pertemuan, dengan pertemuan pertama diadakan pretest sebelum kegiatan pembelajaran dimulai dan diakhir pertemuan diadakan posttest setelah kegiatan pembelajaran berakhir, seperti tampak pada Tabel 1.

Tabel 1. Jadwal Pelaksanaan Kegiatan Pembelajaran

\begin{tabular}{|c|c|l|l|}
\hline Pertemuan & $\begin{array}{c}\text { Kegiatan } \\
\text { Siswa }\end{array}$ & Hari, Tanggal & \multicolumn{1}{|c|}{ Materi } \\
\hline I & $\begin{array}{c}\text { Pretest dan } \\
\text { LAS 1 }\end{array}$ & $\begin{array}{l}\text { Senin, 22 Januari } \\
2018\end{array}$ & $\begin{array}{l}\text { Pretest dan konsep } \\
\text { eksponen }\end{array}$ \\
\hline II & LAS 2 & $\begin{array}{l}\text { Selasa, 23 Januari } \\
2018\end{array}$ & $\begin{array}{l}\text { Fungsi dan sifat- } \\
\text { sifat eksponen }\end{array}$ \\
\hline III & $\begin{array}{c}\text { LAS 3 dan } \\
\text { Posttest }\end{array}$ & $\begin{array}{l}\text { Rabu, 24 Januari } \\
2018\end{array}$ & $\begin{array}{l}\text { Konsep logaritma, } \\
\text { sfat-sifat logaritma, } \\
\text { dan posttest }\end{array}$ \\
\hline
\end{tabular}

Pembelajaran konsep dan sifat-sifat logaritma dilakukan dikelas X MIPA 1 dengan menggunakan instrumen tes tertulis yang telah divalidasi sebelumnya. Pada materi konsep eksponen dan sifat dasar logaritma kegiatan pembelajaran dilaksanakan dengan menggunakan bantuan alat peraga yaitu pola lipatan kertas. Dari pembelajaran, didapatkan hasil observasi kegiatan pembelajaran logaritma berupa catatan lapangan dan analisis data tes tertulis. Berikut penjabaran kegiatan guru, kegiatan siswa dan hasil data tes tertulis dalam pembelajaran logaritma:

1. Deskripsi dan Analisis Kegiatan Pembelajaran Logaritma

a. Pertemuan I

Pada awal pembelajaran guru menyapa siswa kemudian mengecek kehadiran siswa. Selanjutnya, guru menginformasikan bahwa akan diadakan pretest selama 45 menit sebelum kegiatan pembelajaran dimulai. Guru mengawasi siswa pada saat mengerjakan soal pretest. Setelah pretest selesai, guru memulai kegiatan pembelajaran dengan memberikan arahan kepada siswa untuk berdiskusi menggunakan bantuan Lembar Aktivitas Siswa (LAS). Guru meminta siswa untuk teliti dalam mengerjakan LAS, dikarenakan siswa terbiasa tidak membaca perintah sehingga siswa seringkali menanyakannya kepada guru apa yang harus dilakukan.

Pada saat siswa mengerjakan LAS, guru berkeliling kelas untuk mengecek pekerjaan dan memberikan bantuan kepada siswa yang mengalami kesulitan. Salah satu kasus kesulitan yang didapatkan yaitu siswa asal melipat kertas tanpa mengamati pola bidang lipatan yang terbentuk. Berikut ini cuplikan percakapannya:

Guru : Nah, iki disederhanake iki. Oh loh kok ini belum diisi? Ini di isi dulu. Kamu jangan main lipet-lipet aja. Manut petunjuk, lipet 3 piye? Ngono.

Siswa: Gini bu? 1. (Sambil melipat kertas)

Guru : He'eh.

Siswa : 2. (Sambil melipat kertas lagi)

Guru : Nah lipetanmu wis akeh nanti kowe dadi bingung.

Selain itu, terdapat seorang siswa yang bertanya kepada guru karena mengalami kesulitan untuk menentukan pola perkalian pada tabel observasi dalam LAS. Dengan sigap guru membimbing siswa untuk menemukan pola perkalian yang diminta sesuai dengan LAS. Guru sesekali memberikan reward berupa pernyataan "Good idea" kepada siswa yang mengerjakan aktivitas 1 dalam LAS dengan benar.

Berbeda dari aktivitas sebelumnya, pada aktivitas 2 siswa diberikan suatu hasil penelitian mengenai pertumbuhan bakteri. Siswa diminta untuk dapat menemukan model matematika eksponen yang dapat dibentuk dari data hasil penelitian tersebut. Pada saat siswa mengerjakan aktivitas 2 LAS, guru juga berkeliling kelas untuk melihat pekerjaan siswa, Terdapat siswa yang 
JURNAL GANTANG. Maret 2018; III(1): 31 - 39

kesulitan untuk memahami pola cara pertumbuhan bakteri pada setiap jamnya, sehingga siswa bingung untuk menuliskannya kedalam pola tabel pada LAS yang telah disediakan. Kegiatan selanjutnya adalah mempresentasikan hasil diskusi aktivitas 1 dan aktivitas 2.

Kegiatan selanjutnya yaitu, guru mereview kembali materi pembelajaran yang telah dipelajari dengan cara menuliskan konsep eksponen di papan tulis, kemudian guru mendikte siswa mengenai definisi eksponensial. Setelah siswa selesai menulis, guru menginformasikan materi yang akan dipelajari untuk pertemuan selanjutnya dan menyarankan siswa untuk mempelajarinya terlebih dahulu dirumah.

b. Pertemuan II

Pada awal kegiatan pembelajaran, guru memerintahkan siswa untuk memahami aktivitas-aktivitas pada LAS dan mengingatkan siswa agar lebih teliti dalam mengerjakan aktivitas-aktivitas LAS. Selanjutnya, siswa berdiskusi dengan teman sebangkunya, sedangkan guru berkeliling kelas untuk melihat hasil pekerjaan siswa dan membimbing siswa yang mengalami kesulitan.

Kesulitan-kesulitan yang dialami siswa diantaranya adalah siswa bingung dalam menggambarkan grafik fungsi eksponen pada sistem koordinat Kartesius. Kesulitan siswa selanjutnya, siswa kurang memahami aktivitas 2 mengenai makna dari penulisan waktu yang dilambangkan dengan $t$. Kesulitan siswa juga terlihat pada saat menentukan nilai dari $2^{\frac{1}{2}}$. Nilai tersebut merupakan langkah yang digunakan sebelum menentukan volume bakteri setelah 1 jam. Berikut penggalan dialognya:

Guru : Ini kan berarti berapa?

Siswa 1 : Setengah.

Guru : Berarti ini setengah. Saiki pangkat setengah podo karo opo?
Siswa 1 : Akar.

Guru : Akar, berarti $128 \times \sqrt{2} \cdot \sqrt{2}$ itu mendekati berapa?

Siswa 2 : 1 koma 0 koma 7.

Guru : Maksudmu ki 1 koma 0 koma 7 ki piye? Mendekati berapa nak $\sqrt{2}$ ?

Siswa $2: 1,4$ ?

Guru : Nah, kuwe sing bener.

Kegiatan selanjutnya adalah mempresentasikan hasil diskusi aktivitas 1 dan aktivitas 2. Selanjutnya, guru mereview kembali materi pembelajaran yang telah dipelajari mengenai fungsi dan sifat-sifat eksponen. Selanjutnya, guru menginformasikan materi yang akan dipelajari untuk pertemuan selanjutnya yaitu materi logaritma. Selain itu, guru juga menyarankan siswa untuk mempelajari materi logaritma terlebih dahulu dirumah agar pertemuan selanjutnya sudah sedikit memahami tentang logaritma.

\section{c. Pertemuan III}

Pada awal kegiatan pembelajaran, guru memerintahkan siswa untuk membaca dengan teliti perintah dari aktivitas-aktivitas pada LAS. Kemudian siswa diperbolehkan berdiskusi dengan teman sebangkunya untuk menyelesaikan LAS. Selanjutnya, guru berkeliling kelas untuk melihat hasil pekerjaan siswa dan membimbing siswa yang mengalami kesulitan.

Kegiatan diskusi siswa pada aktivitas 1 dan 2 siswa terlihat lebih tenang jika dibandingkan dengan pertemuan-pertemuan sebelumnya. Hal ini juga terlihat pada saat guru mengelilingi kelas, guru lebih banyak mengecek hasil pekerjaan siswa bahwa pekerjaan siswa sudah benar dibandingkan untuk membimbing siswa yang mengalami kesulitan. Sedangkan kesulitan yang dialami siswa adalah sulit untuk megeneralisasikan model matematika kedalam bentuk logaritma sesuai dengan definisi logaritma. Berikut kutipan dialognya: 
Dialog 9

Siswa : Bu.

Guru : Sek baleni, ini yaa dari mana ini? Ini apa ini? Opo neng kene? (menunjuk LAS siswa)

Siswa $: M_{0}$.

Guru $: M_{0}$, iki sopo?

Siswa : Bunganya.

Guru : Bunganya, nah neng kene kan ana tulisane. Terus iki opone?

Siswa : $t$ nya

Guru : $t$ nya, dadi nek ditulis piye neng kene?

Siswa : Dipangkatkan.

Guru : Iya, jadi disini kita menemukan rumus.

Siswa : Bukan hasilnya ya bu?

Guru : Bukan, hasil kan wes ana neng ngarep.

Kesulitan yang dialami siswa adalah siswa sulit untuk memahami pola yang terbentuk utnuk membuktikan sifat penjumlahan dan pengurangan logaritma. Hal ini dikarenakan siswa mengambil nilai $t$ yang bukan merupakan bilangan bulat.

Kegiatan berikutnya yaitu, guru mereview kembali materi pembelajaran yang telah dipelajari mengenai konsep dan sifat-sifat logaritma dengan cara menunjuk beberapa siswa secara bergantian untuk menuliskan kesimpulan LAS dipapan tulis. Selanjutnya, guru menginformasikan bahwa akan diadakan posttest, namun sebelumnya siswa diperkenankan untuk belajar kembali dan membaca sifat-sifat logaritma yang lain pada modul pegangan siswa selama 15 menit sebelum posttest.

2. Deskripsi dan Analisis Data Tes Tertulis

Data tes tertulis digunakan untuk mengetahui kemampuan siswa pada materi konsep dan sifat-sifat logaritma. Tes tertulis dilaksanakan pada pertemuan pertama (pretest) dan terakhir (posttest). Pretest dilaksanakan untuk mengetahui kemampuan awal siswa sebelum diberikan treatment, sedangkan posttest dilaksanakan untuk mengetahui kemampuan siswa setelah diberikan treatment.

Hasil tes tertulis posttest nomor 1 terdapat 4 siswa yang nilainya belum sempurna, sedangkan 28 siswa lainnya sudah benar. Keempat siswa tersebut adalah Desta, Hanifah, Maya, dan Mita. Selanjutnya, dari keempat siswa tersebut memiliki jawaban yang sama persis.

Maya sebenarnya sudah menuliskan rumus dengan benar. Namun, kesalahannya terdapat pada baris ketiga yaitu operasi dari $\left(1+\frac{6}{100}\right)^{8}=1+1,6$. Oleh karena itu, hasil akhir yang didapatkannya juga salah, seperti tampak pada Gambar 1.

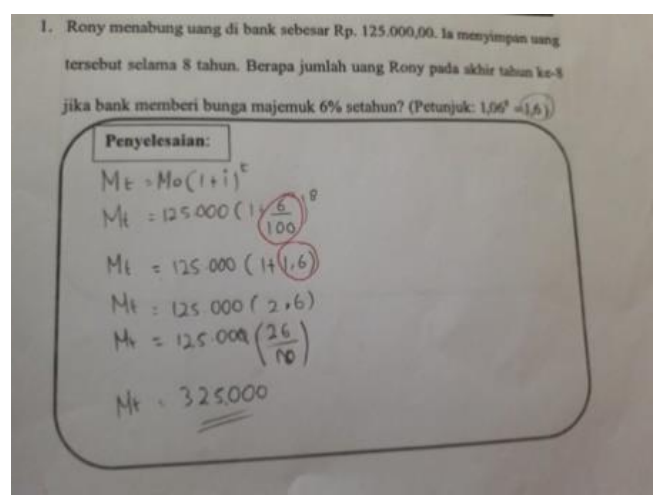

Gambar 1. Jawaban Tes Tertulis Maya Nomor 1

Selanjutnya, hasil evaluasi menunjukkan bahwa hanya terdapat 2 orang siswa yang jawabannya belum benar yaitu Ade dan Hafizhah.

Ade belum dapat mengubah bentuk logaritma ke bentuk eksponen dan tidak terdapat kesimpulan dari soal pembuktian tersebut. Sedangkan Hafizhah belum memahami definisi dari logaritma.

Selanjutnya, terdapat 23 siswa dapat menjawab soal nomor 3 dengan benar dan beberapa diantaranya ada yang sudah sangat mendekati benar hanya kurang dalam 
JURNAL GANTANG. Maret 2018; III(1): 31 - 39

menyederhanakan operasi bilangan pecahan. Sedangkan siswa lainnya masih terdapat beberapa kesalahan, peneliti mengelompokkannya menjadi 4 tipe kesalahan. Tipe kesalahan nomor 3 yang pertama dari siswa yang bernama Usamah menjabarkan nilai logaritma yang ditanyakan tetapi terdapat 1 nilai logaritma yang tidak dapat diubah ke bentuk $m$ maupun $n$. Tipe kesalahan nomor 3 yang kedua adalah siswa melakukan kanselasi numerus pada suatu nilai logaritma. Siswa yang melakukan kesalahan ini adalah Athaya, Hanifah, dan Mita. Tipe kesalahan nomor 3 yang ketiga dialami oleh Ade, Hermawan, dan Sesa. Kesalahannya yaitu menjabarkan basis logaritma menjadi operasi perkalian dua angka yang berbeda. Tipe kesalahan untuk nomor 3 yang terakhir dialami oleh Anendra dan Roihatul. Kesalahan tersebut adalah salah dalam menjabarkan nilai logaritma.

Hasil evaluasi untuk soal nomor 4 menunjukkan bahwa soal nomor merupakan soal yang paling banyak mengecoh siswa, karena dari 32 siswa hanya 7 orang siswa yang dapat menjawab dengan benar. Kesalahan-kesalahan yang dialami siswa dikelompokkan menjadi 2 tipe kesalahan. Kesalahan yang pertama merupakan kesalahan yang sederhana karena hanya kurang teliti dalam menghitung operasi nilai dari suatu pecahan. Tipe kesalahan yang kedua adalah kurang memahami dengan baik salah satu sifat logaritma. Siswa yang melakukan kesalahan ini sebanyak 20 siswa.

Hasil evaluasi soal nomor 5 menunjukkan bahwa sebanyak 16 siswa masih kurang tepat dalam menyelesaikan soal tersebut. Kesalahan pertama yang dialami siswa adalah siswa kurang teliti dalam mengubah suatu nilai logaritma. Kesalahan siswa yang kedua adalah siswa melakukan kanselasi antara basis dengan numerus tanpa memperhatikan pangkat dari numerusnya. Kesalahan selanjutnya yang dialami siswa untuk soal nomor 5 adalah siswa kurang teliti dalam menghitung operasi perkalian, hal ini dikarenakan cara penulisan yang kurang jelas. Berdasarkan hasil evaluasi tes tertulis, terdapat seorang siswa yang memiliki nilai pretest dan posttest yang konstan yaitu Asnan Husen dengan nilai 90. Kesalahan yang dialami Asnan pada saat pretest dan posttest sama, yaitu pada nomor 3 Asnan belum menyederhanakan bentuk pecahan, sedangkan pada nomor 4 kurang teliti dalam mengoperasikan bilangan pecahan. Hasil lainnya menunjukkan bahwa terdapat 1 siswa yang mendapatkan nilai 100 yaitu Redita Ratna Wulandari. Kriteria Ketuntasan Minimum (KKM) SMA Negeri 1 Jetis Bantul Yogyakarta untuk mata pelajaran Matematika adalah 77. Selanjutnya, penjelasan nilai pretest dan posttest siswa kelas X MIPA 1 SMA Negeri 1 Jetis Bantul Yogyakarta dapat dilihat pada Tabel 2 .

Tabel 2. Kategori Nilai Prestest dan Posttest Siswa

\begin{tabular}{|c|c|c|c|c|c|}
\hline Kategori & Nilai & $\begin{array}{c}\text { Frekuensi } \\
\text { (pretest) }\end{array}$ & $\begin{array}{c}\text { Persentase } \\
\text { (pretest) }\end{array}$ & $\begin{array}{c}\text { Frekuensi } \\
\text { (posttest) }\end{array}$ & $\begin{array}{c}\text { Persentase } \\
\text { (posttest) }\end{array}$ \\
\hline Tuntas & $\geq 77$ & 3 & $9,677 \%$ & 21 & $65,625 \%$ \\
\hline $\begin{array}{c}\text { Tidak } \\
\text { tuntas }\end{array}$ & $<77$ & 28 & $90,323 \%$ & 11 & $34,375 \%$ \\
\hline
\end{tabular}

Siswa yang tuntas pada saat pretest sebanyak $9,677 \%$, sedangkan sisanya tidak tuntas, seperti ditunjukkan pada Tabel 2. Kegiatan pretest diikuti oleh 31 siswa karena pada pertemuan pertama tersebut siswa yang hadir hanya 31 siswa. Selanjutnya, tes tertulis posttest diikuti oleh 32 siswa dan hasilnya sebanyak $65,625 \%$ siswa tuntas dan $34,375 \%$ siswa. Rata-rata nilai pretest siswa adalah 37,387, sedangkan rata-rata nilai posttest siswa adalah 77,531.

Pada pertemuan pertama aktivitas 1 siswa diajak untuk mengenal konsep eksponen melalui pola bidang pada lipatan-lipatan kertas. Saat berkeliling guru mendapatkan siswa yang asal melipat-lipat kertas sehingga pola bidang lipatan dikertas sulit dilihat. Oleh karena itu, 
guru memperingati siswa untuk membaca perintah pengerjaan LAS secara teliti. Setelah siswa membaca ulang perintah tersebut, siswa secara perlahan dapat melipat kertas dengan benar sehingga pola bidang pada lipatan-lipatan kertas terlihat dengan jelas. Kemudian pada aktivitas 2, kesulitan yang dialami siswa adalah siswa sulit memahami pola cara pertumbuhan bakteri untuk setiap waktunya, oleh karena itu mengakibatkan siswa bingung untuk menuliskannya kedalam pola tabel yang telah disediakan dalam LAS. Hal ini sesuai dengan pernyataam Adrelia, Kurniawati, dan Prahmana (2015) bahwa siswa memiliki pola pikir yang abstrak sehingga siswa mengalami kesulitan untuk menerapkan matematika dalam kehidupan sehari-hari.

Guru membimbing siswa melalui ilustrasi peristiwa yang ada di kehidupan seharihari. Salah satu ilustrasinya dalam bentuk cerita perkembangbiakan ayam agar siswa lebih dapat memahami, seperti tampak pada Gambar 2.

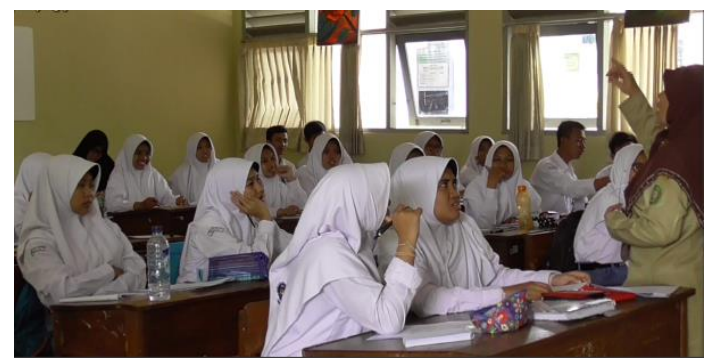

Gambar 2. Guru Membimbing Siswa untuk Membantu Menemukan Konsep

Tindakan bimbingan yang dilakukan oleh guru tanpa memberikan secara langsung konsep eksponen ini merupakan tindakan guided reinvention pada PMR atau yang biasa dikenal dengan model pembelajaran guided inquiry. Hal ini sejalan dengan yang dinyatakan oleh Lestari dan Prahmana (2017) bahwa dalam pembelajaran guided inquiry guru dilarang untuk mejelaskan konsep, sifat-sifat, maupun jawaban atas materi yang sedang dipelajari oleh siswa.

Pada pertemuan kedua materi yang dipelajari adala fungsi eksponen dan sifat eksponen. Sama halnya seperti pada pertemuan pertama, terdapat beberapa siswa yang mengalami kesulitan dalam mengerjakan LAS karena kurang teliti dalam membaca perintah. Kesulitan tersebut diantaranya adalah siswa tidak tahu bagaimana cara menggambar grafik fungsi eksponen pada sistem koordinat kartesius dan siswa kurang memahami penulisan waktu yang dilambangkan dengan $t$. Kesulitan siswa lainnya adalah siswa bingung dalam menentukan nilai dari $2^{\frac{1}{2}}$

Pada saat pertemuan-pertemuan sebelumnya materi yang dipelajari adalah eksponen yang merupakan materi prasyarat untuk mempelajari konsep dan sifat-sifat logaritma. Sejalan dengan yang dinyatakan oleh Nugraheni dan Sugiman (2013) bahwa siswa harus mempelajari materi konsep prasyarat terlebih dahulu sebelum mempelajari konsep matematika selanjutnya. Suasana pembelajaran pada pertemuan terakhir ini terlihat lebih baik, karena siswa dapat lebih memahami aktivitasaktivitas pada LAS. Hal ini karena pada pertemuan sebelumnya siswa selalu diperingatkan oleh guru agar lebih teliti dalam membaca perintah soal, sehingga saat siswa lebih teliti siswa dapat menyelesaikannya dengan lebih mudah. Selama kegiatan pembelajaran pada pertemuan ketiga ini banyak siswa yang melakukan konfirmasi kepada guru mengenai hasil diskusinya dengan teman. Selain itu, terdapat kesulitan yang dialami siswa yaitu siswa sulit untuk megeneralisasi model matematika kedalam bentuk logaritma pada aktivitas 1 dan siswa sulit memahami pola yang dihasilkan untuk membuktikan sifat penjumlahan dan pengurangan logaritma.

Hasil tes tertulis menunjukkan bahwa masih terdapat siswa yang belum dapat menyelesaikan soal-soal tes dengan benar. Kesalahan-kesalahan siswa dalam mengerjakan soal-soal tes tertulis disebabkan oleh kurang teliti dalam menghitung operasi bilangan pecahan, siswa kurang memahami syarat nilai basis pada logaritma. Kesalahan lainnya adalah cara penulisan siswa yang kurang jelas sehingga 
siswa bingung sendiri dan mengakibatkan salah hitung yang sebenarnya operasi perkalian antar bilangan negatif berubah menjadi operasi pengurangan. Selain itu, siswa kurang memahami sifat-sifat logaritma sehingga siswa sering menjabarkan suatu nilai logaritma secara aljabar tanpa memperhatikan aturan-aturan dalam logaritma.

Berdasarkan hasil penelitian, pembelajaran logaritma menggunakan LAS berbasis PMR merupakan suatu hal baru bagi sehingga selama kegiatan pembelajaran logaritma pada pertemuan 1 dan pertemuan 2 siswa masih beradaptasi belajar dengan menggunakan bantuan LAS dan masih sering kurang teliti dalam membaca perintah sehingga siswa mengalami kesulitan untuk menyelesaikan aktivitas-aktivitas pada LAS, sedangkan pada pertemuan ketiga siswa sudah lebih baik dalam memahami LAS yang diberikan sehingga dapat mengerjakannya dengan baik. Hal ini sejalan dengan penelitian sebelumnya (Webb, van der Kooij, dan Geist, 2011), sehingga memberikan penegasan mengenai implementasi pembelajaran logaritma melalui pendekatan pembelajaran PMR.

\section{Penutup}

Dalam pembelajaran logaritma melalui Lembar Aktivitas Siswa (LAS) berbasis pendekatan pembelajaran Pendidikan Matematika Realistik (PMR), guru membimbing siswa untuk menemukan konsep dan sifat-sifat logaritma melalui peristiwa yang ada dikehidupan sehari-hari. Selain itu, pada saat pengenalan konsep eksponen dan sifat dasar logaritma siswa diajak untuk melakukan eksperimen dengan cara menemukan pola bidang yang terbentuk pada lipatan-lipatan selembar kertas. Selanjutnya, pada pertemuan pertama dan kedua siswa terlihat masih beradaptasi dengan desain pembelajaran yang diterapkan, namun pada pertemuan berikutnya siswa sudah mulai dapat mengikuti kegiatan pembelajaran dengan lebih baik.

Hasil belajar siswa setelah diberikan treatment desain pembelajaran logaritma menunjukkan bahwa nilai rata-rata yang diperoleh siswa adalah 77,531 dengan frekuensi ketuntasan $65,625 \%$ atau sebanyak 21 siswa yang nilainya diatas Kriteria Ketuntasan Minimum (KKM). Selain itu, salah seorang siswa dapat memperoleh nilai 100 pada tes tertulis tersebut.

\section{Ucapan Terimakasih}

Peneliti mengucapkan banyak terimakasih kepada pihak sekolah SMA Negeri 1 Jetis Bantul Yogyakarta yang telah mengizinkan peneliti untuk melakukan penelitian di kelas X MIPA 1 tahun ajaran 2017/2018 dan Universitas Ahmad Dahlan sebagai tempat peneliti melakukan kajian literatur.

\section{Daftar Pustaka}

Adrelia, D. I., Kurniawati, V., \& Prahmana, R. C. I. (2015). Permainan Bom Angka dalam Konsep Kelipatan Persekutuan Terkecil untuk Anak Sekolah Dasar. Jurnal Elemen, 1(1), 25-35.

Fitirani, N. (2016). Hubungan Antara Kemampuan Pemecahan Masalah Matematis dengan Self Confidence Siswa SMP yang Menggunakan Pendekatan Pendidikan Matematika Realistik. Euclid, 2(2), 341-351.

Freudenthal, H. (2002). Revisiting Mathematics Education. New York: Kluwer Academic Publisher

Hadi, S. (2017). Pendidikan Matematika Realistik Teori, Pengembangan, dam Implementasinya. Jakarta: PT Rajawali Pers.

Hamdani, M. A. (2011). Strategi Belajar Mengajar. Bandung: Pustaka Setia.

Kemendikbud. (2016). Permendikbud Nomor 24. Kusuma, H. \& Masduki. (2016). Pemahaman Matematika Berbasis Tingkat Kemampuan Siswa Materi Logaritma. Prosiding Seminar Nasional Pendidikan Matematika, (hal. 1-7). Surakarta: Universitas Muhammadiyah Surakarta.

Lestari, R. M, \& Prahmana, R. C. I. (2017). Model Guided Inquiry, Student Teams Achievement Division, dan Kemampuan Penalaran Matematis Siswa. Beta Jurnal 
Tadris Matematika, 10(2), 153-165.

Negara, H. S., Sujadi, I., \& Pangadi. (2013). Analisis Pembelajaran Matematika pada Sekolah yang Menerapkan Pendekatan PMRI dan Sekolah yang Tidak Menerapkan Pendekatan PMRI di Kota Yogyakarta. Jurnal Elektronik Pembelajaran Matematika, 1(7), 700-711.

Novianda, R., Sudaryati, S., \& Meiliasari. (2014). Mengembangkan Pemahaman Matematika Siswa terhadap Materi Sistem Persamaan Linear Dua Variabel (SPLDV) dengan Pendidikan Matematika Realistik Indonesia (PMRI) di SMP Negeri 1 Tambun Selatan. JMAP, 13(1), 119-131.

Nugraheni, E. A., \& Sugiman. (2013). Pengaruh Pendekatan PMRI terhadap Aktivitas dan Pemahaman Konsep Matematika Siswa SMP. PYTHAGORAS: Jurnal Pendidikan Matematika, 8(1), 101-108.

Nurhayanti, H., Suripto., \& Suyanto, I. (2016). Penerapan Pendekatan Pendidikan Matematika Realistik (PMR) dengan Media Visual dalam Peningkatan Pembelajaran Matematika pada Siswa Kelas V SDN 2 Krandegan. Kalam Cendekia PGSD Kebumen,4(1), 64-68.

Pawestri, U., Soeyono., \& Kurniawati, I. (2013). Analisis Kesulitan Pembelajaran Matematika dengan Pengantar Bahasa Inggris pada Materi Pokok Bentuk Logaritma Kelas X Imersi SMA Negeri Karangpandan Karanganyar 2012/2013. Jurnal Pendidikan Matematika Solusi, l(1), 1-7.

Permatasari, D., \& Harta, I. (2018). The gap between the beginning and the end of algebraic thinking transition period. International Journal on Emerging Mathematics Education, 2(1), 79-88.

Prahmana, R. C. I. (2017). Design Research (Teori dan Implementasinya: Suatu Pengantar). Jakarta: Rajawali Pers.

Prahmana, R. C. I., Zulkardi., \& Hartono, Y. (2015). Learning Multiplication Using Indonesian Traditional game in Third Grade. Journal on Mathematics Education, 3(2), 115-132.

Putri, R. I. I., Dolk, M., \& Zulkardi. (2015).
Professional Development of PMRI Teachers for Introducing Social Norms. Journal on Mathematics Education, 6(1), 11-19.

Revina, S., \& Leung, F.K.S. (2018). Educational borrowing and mathematics curriculum: Realistic Mathematics Education in Dutch and Indonesian curriculum. International Journal on Emerging Mathematics Education, 2(1), 1-16.

Ryandi, R.B., Somakim, \& Susanti, E. (2018). Learning combinations through "Handshake". International Journal on Emerging Mathematics Education, 2(1), 105-118.

Sari, P., Hadiyan, A., \& Antari, D. (2018). Exploring derivatives by means of GeoGebra. International Journal on Emerging Mathematics Education, 2(1), 65-78.

Sembiring, R. K. (2010). Pendidikan Matematika Realistik Indonesia (PMRI): Perkembangan dan Tantangannya. Journal on Mathemathics Education, 1(1), 11-16.

Sinaga, B., Sinambela, P. N. J. M., Sitanggang, A. K., Hutapea, T. A., Sinaga, L. P., Manullang, S., Simanjorang, M., \& Bayuzetra, Y. T. (2014). Buku Guru Matematika. Jakarta: Kementerian Pendidikan dan Kebudayaan.

Webb, D. C., van der Kooij, H. \& Geist, M. R. (2011). Design Research in the Netherlands: Introducing Logarithms Using Realistic Mathematics Education. Journal of Mathematics Education at Teachers College,2(1), 47-52.

Widowati, S. (2013). Pengembangan Buku Kerja Materi Eksponen Bercirikan RME untuk Siswa SMK Teknik. Jurnal Pendidikan Sains, 1(3), 265-273.

Wijaya, A. (2012). Pendidikan Matematika Realistik Suatu Alternatif Pendekatan Pembelajaran Matematika. Yogyakarta: Graha Ilmu. 
JURNAL GANTANG. Maret 2018; III(1): 31 - 39

p-ISSN. 2503-0671

e-ISSN. 2548-5547 